\title{
Article \\ Effect of Pesticide and Humic Preparation on the Soil Structure
during Pea and Chickpea Cultivation
}

Olga Bezuglova *, Andrey Gorovtsov, Artem Grinko, Semyon Kartashev, Alexander Klimenko, Vladimir Lykhman, Evgeny Patrikeev and Elena Polienko [D

check for

updates

Citation: Bezuglova, O.; Gorovtsov,

A.; Grinko, A.; Kartashev, S.;

Klimenko, A.; Lykhman, V.; Patrikeev,

E.; Polienko, E. Effect of Pesticide and

Humic Preparation on the Soil

Structure during Pea and Chickpea

Cultivation. Agronomy 2021, 11, 2053.

https://doi.org/10.3390/

agronomy11102053

Academic Editors: Evgeny Lodygin and Elena Shamrikova

Received: 31 August 2021

Accepted: 8 October 2021

Published: 13 October 2021

Publisher's Note: MDPI stays neutral with regard to jurisdictional claims in published maps and institutional affiliations.

Copyright: (c) 2021 by the authors. Licensee MDPI, Basel, Switzerland. This article is an open access article distributed under the terms and conditions of the Creative Commons Attribution (CC BY) license (https:// creativecommons.org/licenses/by/ $4.0 /)$.
Federal Rostov Agrarian Scientific Center, 346735 Rassvet, Rostov Region, Russia; gorovtsov@gmail.com (A.G.); grinko82@mail.ru (A.G.); semyonrus357@gmail.com (S.K.); dzni@mail.ru (A.K.); lykvladimir@yandex.ru (V.L.); onyx134679852@gmail.com (E.P.); polienkoe468@gmail.com (E.P.)

* Correspondence: lola314@mail.ru

Abstract: The article presents the results of a 3-year experiment to study the soil structure with the combined use of insecticides and a humic preparation. Crops were peas (Pisum sativum) and chickpeas (Cicer arietinum). The experiment was carried out in 2019-2021 at the experimental fields of the Federal Rostov Agrarian Scientific Center, located in the Rostov region in the south of the European part of Russia $\left(47^{\circ} 21^{\prime}\right.$ N, $39^{\circ} 52^{\prime}$ E). Soil was Calcic Chernozem Loamic. The studies were carried out both without fertilization and with the use of mineral fertilizers (N40P40K40). Sowings of leguminous crops were treated with a mixture of insecticides and a humic preparation in the phase of bean formation. The humic preparation BIO-Don10 was obtained according to the authors' technology by alkaline extraction from vermicompost-a product of manure processing by compost worms of the Eisenia foetida species. The preparation contains salts of humic acids and fulvic acids in the amount of $1.9 \mathrm{~g} / \mathrm{L}$; the concentration in the mixture with the insecticide was $0.002 \%$. An increase in the structure and water resistance coefficients was observed. A decrease in the block fraction and an increase in the total number of agronomically valuable aggregates were substantiated. It was found that in the cultivation of legumes, the application of mineral fertilizers had a negative effect on the structure of the soil, while, when using pesticides, the structure was preserved better by the end of the growing season. The revealed patterns can be associated with the activity of microorganisms participating in the hydrolysis of organic compounds that stabilize soil aggregates.

Keywords: humic preparations; pesticides; peas; soil structure; water resistance; Calcic Chernozem

\section{Introduction}

At the present stage of human development, large-scale agricultural production is impossible without the use of mineral fertilizers and pesticides. However, their use has negative environmental consequences and, therefore, agriculture is currently focused on the use of resource-saving technologies and methods of biological farming in order to ensure environmental safety. One of the components of biological agriculture is the use of humic fertilizers and preparations, which is due to their affinity for soil organic matter.

Humic substances determine the basis of soil fertility [1-3]. Therefore, the increased interest in this class of natural polymers as a means of solving many environmental problems is understandable. Humic preparations can increase the availability of nutrients in the soil, thereby stimulating plant growth and development [4-9]. They interact with heavy metals, altering their mobility and preventing entry into adjacent environments and plants [10-13]. Humic fertilizers are also used to neutralize toxic aromatic hydrocarbons and reduce pesticidal stress in plants [14-16].

Both organic minerals (peat, brown coal, sapropel) and composts, industrial waste can serve as raw materials for obtaining humic preparations and fertilizers [17-20].

One of the most important morphological and agrophysical properties of the soil is its structure. Influencing the thermal, air, and water regimes, the structure also plays 
an important role in the formation of soil fertility [21]. The structure of the soil and its properties is largely related to the amount and quality of organic matter-humus [22-25]. Due to their affinity for soil organic matter, humic fertilizers also have a positive effect on the structure of the soil [26-28]. Humic preparations, in contrast to humic fertilizers, are purified concentrates of humic substances. They are used for plant treatments, solely or in tank mixtures with pesticides, which contribute to an increase in the productivity of various agricultural crops. This increase is both due to a stimulating effect on the plant growth and due to reduction or complete neutralization of the side stress effect from pesticides [16,29]. However, the effect of such treatments on soil characteristics, and especially on physical properties, has not been sufficiently studied.

The aim of the study was to determine and analyze the structural state of the soil using the humic preparation BIO-Don10 as a part of a tank mixture with pesticides on legumes: peas and chickpeas.

\section{Material and Methods}

\subsection{Research Object and Location}

The objects of research were two legume crops, chickpeas (variety "Donplaza") and peas (variety "Alliance"), levels of mineral nutrition of plants, chemical plant protection products, and humic preparation BIO-Don10.

The studies were carried out at the Agrochemistry and Plant Protection Station of the Federal Rostov Agrarian Scientific Center (FRASC); soil type was Calcic Chernozem Loamic. Distinctive features of this subtype of chernozems include the thickness of the humus horizon exceeding $80 \mathrm{~cm}$, with a humus content in the arable layer of $3.6-4.2 \%$, a high level of carbonate content (effervescence from $10 \% \mathrm{HCl}$ in horizon $\mathrm{A}$ at a depth of $35-40 \mathrm{~cm}$ ), and a granular-lumpy structure. Elementary soil particles are coagulated into solid aggregates, the predominant part of which belongs to agronomically valuable fractions with a size of $10-0.25 \mathrm{~mm}$. The sum of absorbed bases in the arable layer is on average $40 \mathrm{mg}$-eq $/ 100 \mathrm{~g}$ of soil. It predominantly contains calcium (85-90\%), magnesium (about $10 \%$ ), and sodium less than $1.0 \%$. The density of the soil in the arable layer ranges from 1.0 to $1.2 \mathrm{~g} / \mathrm{cm}^{3}$. The arable layer has quite satisfactory porosity, $50-66 \%$ of the soil volume, providing high air capacity and gas exchange.

The south of the Rostov region is characterized as a zone of insufficient and unstable moisture. The years of research differed significantly in terms of the hydrothermal regime. In the growing season of 2019, the amount of precipitation fell extremely unevenly compared with the long-term average values, and for the whole period the precipitation turned out to be almost 1.5 times lower than the long-term average. Together with high average temperatures, this led to a lack of soil moisture throughout the growing season. The hydrothermal coefficient for the growing season was 0.72. In 2020, the trend towards an increase in aridity continued; the value of the hydrothermal coefficient was even lower, 0.54 . The growing season of 2021 was characterized by a more even distribution of precipitation by months, its total amount was $82 \mathrm{~mm}$ higher than in 2020, and the hydrothermal coefficient was 0.95 . Soil moisture at the time of sowing was $25-30 \%$ in different years of research (GOST 28268-89). The sampling of soil for moisture determination was carried out pointwise using a drill. Sampling for structural, aggregate, chemical, and microbiological analyses was performed in accordance with GOST R 58595-2019, with a sampling depth of 0-20 cm; a mixed sample was formed by the envelope method from 15 point samples. All samples were taken in triplicates.

Soil samples were taken from the arable layer after harvest.

Treatment with tank mixtures was carried out in the phase of the formation of beans. During this phase, legumes are most vulnerable to cotton bollworm, acacia moth, and pea aphid. At the experimental site, the agricultural technologies for the cultivation of legumes were used, which were recommended for the Azov zone of the Rostov region. 


\subsection{Experimental Layout}

The experimental variants included the average dose of fertilizers and control (without fertilizers) and a plant protection system with the use of standard chemical protection and control (without pesticides) (Tables 1 and 2), as well as the humic preparation BIO-Don10.

Table 1. Experimental layout.

\begin{tabular}{ccccccc}
\hline Variant & \multicolumn{2}{c}{ I Repetition } & \multicolumn{2}{c}{ II Repetition } & \multicolumn{2}{c}{ III Repetition } \\
\hline \multirow{2}{*}{ N40P40K40 } & $\mathrm{CF}{ }^{1}$ & $\mathrm{CF}+\mathrm{H}$ & $\mathrm{CF}$ & $\mathrm{CF}+\mathrm{H}$ & $\mathrm{CF}$ & $\mathrm{CF}+\mathrm{H}$ \\
& $\mathrm{CHF}$ & $\mathrm{CHF}+\mathrm{H}$ & $\mathrm{CHF}$ & $\mathrm{CHF}+\mathrm{H}$ & $\mathrm{CHF}$ & $\mathrm{CHF}+\mathrm{H}$ \\
\hline \multirow{2}{*}{ Control } & $\mathrm{C}$ & $\mathrm{H}$ & $\mathrm{C}$ & $\mathrm{H}$ & $\mathrm{C}$ & $\mathrm{H}$ \\
& $\mathrm{CH}$ & $\mathrm{CH}+\mathrm{H}$ & $\mathrm{CH}$ & $\mathrm{CH}+\mathrm{H}$ & $\mathrm{CH}$ & $\mathrm{CH}+\mathrm{H}$ \\
\hline
\end{tabular}

${ }^{1} \mathrm{C}$-control without the use of fertilizers and pesticides; $\mathrm{CF}-$ control with fertilizers; $\mathrm{CH}-$ with pesticides, without fertilizers; $\mathrm{CHF}$-with pesticides and fertilizers; $\mathrm{H}$ - humic preparation.

Table 2. Chemical plant protection system.

\begin{tabular}{ll}
\hline \multicolumn{1}{c}{ Pesticides } & \multicolumn{1}{c}{ Active Compound, Dose } \\
\hline (1) Herbicide & $\begin{array}{l}\text { Before emergence-prometryn [N2,N4-di-isopropyl-6- } \\
\text { methylthio-1,3,5-triazine-2,4-diamine]-1.5 kg/ha }\end{array}$ \\
\hline & $\begin{array}{l}\text { (1) Budding-dimethoate }[O, O-d i m e t h y l-S-(N- \\
\text { methylcarbamidomethyl)dithiophosphate]-240 g/ha(2) }\end{array}$ \\
(2) Insecticides & $\begin{array}{l}\text { Flowering-deltamethrin [(S)-L-cyano-3- } \\
\text { phenoxybenzyl(1R,3R)-3-(2,2-dibromovinyl)-2,2- } \\
\text { dimethylcyclopropanecarboxylate]-4 g/ha }\end{array}$ \\
\hline (3) Desiccant & Maturation-diquat dibromide \\
& [1,1-ethylene-2,2-dipyridylium dibromide]-300 g/ha \\
\hline
\end{tabular}

Azophos was used as fertilizer; it was applied during the main tillage.

\subsection{Humic Preparation}

Field studies were carried out with an alkaline extract of vermicompost: humic preparation BIO-Don10. It was obtained by alkaline extraction from vermicompost, a product of manure processing (cattle, pork, horse, and also poultry manure) by compost worms of the Eisenia foetida species. The manufacturer is a small business under FRASC authority. The composition contains salts of humic acids (HA) and fulvic acids (FA) in the amount of $1.9 \mathrm{~g} / \mathrm{L}$; the concentration in the mixture with the insecticide was $0.002 \%$ (Table 3).

Table 3. The results of the chemical analysis of the BIO-Don10 humic preparation, manufacturer BIO-Don LLC.

\begin{tabular}{cccc}
\hline Parameter & Unit & Method & Value \\
\hline \multirow{2}{*}{ Dry residue } & $\%$ & GOST 26713-85 & 1.15 \\
& $\mathrm{~g} / \mathrm{L}$ & GOST 27980-88 & 11.46 \\
\hline $\mathrm{C}$ (in dry residue) & $\%$ & Ponomareva and & 16.3 \\
$\mathrm{C}$ (in solution) & $\mathrm{g} / \mathrm{L}$ & Plotnikova method of & 1.9 \\
\hline \multirow{2}{*}{$\mathrm{C}_{\mathrm{HA}}$} & $\%$ & humic and fulvic acids & 8.9 \\
& $\mathrm{~g} / \mathrm{L}$ & determination [30] & 1.02 \\
\hline \multirow{2}{*}{$\mathrm{C}_{\mathrm{FA}}$} & $\%$ & $\mathrm{~g} / \mathrm{L}$ & \\
& & & 0.9 \\
\hline
\end{tabular}

\subsection{Water Resistance of the Microstructure Analysis}

Water resistance of soil aggregates was determined by the Savvinov wet-sieving method. The procedure consists of two parts: fractionation of soil on sieves in an air-dry state (dry sieving) and fractionation on sieves in water (wet sieving) [31]. 
Fractionation of soil in an air-dry state (dry sieving): From a soil sample, an average sample of 0.5 to $2.5 \mathrm{~kg}$ was taken and dispersed on sieves with hole diameters of 10, 7, 5, 3, $2,1,0.5$, and $0.25 \mathrm{~mm}$. The analyzed soil was placed in small portions on the upper, largest sieve and scattered by careful tilting of the entire set of sieves. Each fraction of the aggregates was separately collected and weighed and its percentage calculated. To assess the structure, the structural coefficient was used, which is the ratio of agronomically valuable aggregates $(10-0.25 \mathrm{~mm})$ to agronomically non-valuable aggregates $(>10+<0.25 \mathrm{~mm})$.

Determination of water resistance of aggregates (wet sieving): To determine the water resistance, an average sample of $50 \mathrm{~g}$ was made from all fractions of aggregates obtained by dry sieving, in proportion to their percentage in the particular sample. The set consisted of sieves with hole diameters of $5,3,2,1,0.5$, and $0.25 \mathrm{~mm}$. The water resistance of the structure was assessed by the total content of waterproof aggregates.

\subsection{Microbiological Analysis}

In the soil under the chickpea, the numbers of the main ecological groups of culturable microorganisms were determined by plate count method [32]. The number of copiotrophic bacteria was determined on nutrient agar; prototrophic bacteria were enumerated on starch-ammonium agar (ISP-3). The same medium was also used for enumeration of actinomycetes based on colony morphology and aerial mycelium formation. Actinomycetes are capable of mineralizing hardly decomposable compounds; they play an essential role in the humification processes. The abundance of bacilli was determined on wort agar with $50 \%$ nutrient agar after the pasteurization of soil suspension at $80^{\circ} \mathrm{C}$ for $20 \mathrm{~min}$ [33]. The abundance of culturable microorganisms was evaluated in comparison with their initial number in the soil of each experimental variant: This approach allows one to take into account the changes that do not depend on the experimental conditions. Sampling for microbiological analysis was carried out before treatment and 2 weeks after treatments with pesticides and humic preparation (May 2019, June 2020).

\subsection{Statistical Data Analysis}

Statistical data processing was carried out using one-way analysis of variance (ANOVA). Tukey's test was used as a post hoc test. ANOVA data are presented in the Supplementary (Tables S1-S4). The Fisher's least significant difference method was also used to statistically evaluate changes in the yield of leguminous crops and agrophysical properties of the soil. In addition, principal component analysis was used to reduce the dimensionality of the data and to visualize it. This analysis was applied to the data on the number of microorganisms for the experimental variants, and the selected main components were correlated with agrophysical indicators using the Spearman nonparametric correlation test.

All calculations were performed using Statistica 12 (StatSoft, Tulsa, OK, USA) and SPSS Statistics 26 (IBM, Armonk, New York, NY, USA) software. Microsoft Office Excel 2019 was also used to plot the graphs.

\section{Results}

3.1. Influence of a Humic Preparation on the Yield of Leguminous Crops

Treatment of legumes with a humic preparation led to an increase in yield (Tables 4 and 5). 
Table 4. Yield of chickpeas by variants of the experiment with a humic preparation.

\begin{tabular}{|c|c|c|c|c|c|c|c|c|c|}
\hline \multirow{3}{*}{ Variant } & \multicolumn{3}{|c|}{2019} & \multicolumn{3}{|c|}{2020} & \multicolumn{3}{|c|}{2021} \\
\hline & \multirow{2}{*}{$\begin{array}{l}\text { Yield, } \\
\text { c/ha }\end{array}$} & \multicolumn{2}{|c|}{ Increase in Control } & \multirow{2}{*}{$\begin{array}{l}\text { Yield, } \\
\text { c/ha }\end{array}$} & \multicolumn{2}{|c|}{ Increase in Control } & \multirow{2}{*}{$\begin{array}{l}\text { Yield, } \\
\text { c/ha }\end{array}$} & \multicolumn{2}{|c|}{ Increase in Control } \\
\hline & & c/ha & $\%$ & & c/ha & $\%$ & & c/ha & $\%$ \\
\hline \multicolumn{10}{|c|}{ No fertilizers } \\
\hline $\mathrm{C}$ & 10.5 & & & 9.1 & & & 9.8 & & \\
\hline $\mathrm{H}$ & 11.5 & 1.0 & 9.5 & 12.3 & 3.2 & 35.2 & 11.2 & 1.4 & 14.3 \\
\hline $\mathrm{CH}$ & 12.5 & 2.0 & 19.0 & 10.7 & 1.6 & 17.6 & 10.6 & 0.8 & 8.2 \\
\hline $\mathrm{CH}+\mathrm{H}$ & 13.7 & 3.2 & 30.5 & 14.7 & 5.6 & 61.5 & 12.3 & 2.5 & 25.5 \\
\hline LSD05 & & 1.9 & & & 2.6 & & & 1.2 & \\
\hline \multicolumn{10}{|c|}{ Mineral fertilizer (N40P40K40) } \\
\hline $\mathrm{CF}$ & 12.5 & & & 11.2 & & & 11.3 & & \\
\hline $\mathrm{CF}+\mathrm{H}$ & 13.7 & 1.2 & 9.6 & 14.7 & 3.5 & 31.3 & 12.5 & 1.2 & 10.6 \\
\hline $\mathrm{CHF}$ & 16.2 & 3.7 & 29.6 & 12.5 & 1.3 & 11.6 & 11.7 & 0.4 & 3.5 \\
\hline $\mathrm{CHF}+\mathrm{H}$ & 17.5 & 5.0 & 40.0 & 18.7 & 7.5 & 67.0 & 14.8 & 3.5 & 31.0 \\
\hline LSD05 & & 2.0 & & & 2.9 & & & 1.0 & \\
\hline
\end{tabular}

Table 5. Yield of peas by variants of the experiment with a humic preparation.

\begin{tabular}{|c|c|c|c|c|c|c|c|c|c|}
\hline \multirow{3}{*}{ Variant } & \multicolumn{3}{|c|}{2019} & \multicolumn{3}{|c|}{2020} & \multicolumn{3}{|c|}{2021} \\
\hline & \multirow{2}{*}{$\begin{array}{l}\text { Yield, } \\
\text { c/ha }\end{array}$} & \multicolumn{2}{|c|}{ Increase in Control } & \multirow{2}{*}{$\begin{array}{l}\text { Yield, } \\
\text { c/ha }\end{array}$} & \multicolumn{2}{|c|}{ Increase in Control } & \multirow{2}{*}{$\begin{array}{l}\text { Yield, } \\
\text { c/ha }\end{array}$} & \multicolumn{2}{|c|}{ Increase in Control } \\
\hline & & c/ha & $\%$ & & c/ha & $\%$ & & c/ha & $\%$ \\
\hline \multicolumn{10}{|c|}{ No fertilizers } \\
\hline C & 15.3 & & & 11.7 & & & 13.2 & & \\
\hline $\mathrm{H}$ & 17.2 & 1.9 & 12.4 & 15.5 & 3.8 & 32.5 & 16.1 & 2.9 & 22.0 \\
\hline $\mathrm{CH}$ & 18.5 & 3.2 & 20.9 & 12.8 & 1.1 & 9.4 & 14.4 & 1.2 & 9.1 \\
\hline $\mathrm{CH}+\mathrm{H}$ & 20.1 & 4.8 & 31.4 & 18.1 & 6.4 & 54.7 & 18.3 & 5.1 & 38.6 \\
\hline LSD05 & & 2.2 & & & 3.0 & & & 1.5 & \\
\hline \multicolumn{10}{|c|}{ Mineral fertilizer (N40P40K40) } \\
\hline $\mathrm{CF}$ & 17.8 & & & 13.5 & & & 15.5 & & \\
\hline $\mathrm{CF}+\mathrm{H}$ & 20.8 & 3.0 & 16.9 & 18.7 & 5.2 & 38.5 & 18.9 & 3.4 & 21.9 \\
\hline $\mathrm{CHF}$ & 21.2 & 3.4 & 19.1 & 15.3 & 1.8 & 13.3 & 16.9 & 1.4 & 9.0 \\
\hline $\mathrm{CHF}+\mathrm{H}$ & 23.5 & 5.7 & 32.0 & 21.2 & 7.7 & 57.0 & 20.1 & 4.6 & 29.7 \\
\hline LSD05 & & 2.7 & & & 2.9 & & & 1.2 & \\
\hline
\end{tabular}

For the formation of high yields in the cultivation of agricultural crops, an optimal supply of moisture and nutrients is needed. At the same time, an effective fight against weeds, diseases, and pests is necessary for their preservation.

In 2019, during the growing season of peas and chickpeas, the temperature and moisture conditions were arid (hydrothermal coefficient 0.72 ); but, during the period of active vegetation (March-May), the amount of precipitation was at the level of the average long-term value. In the $0-100-\mathrm{cm}$ layer, productive moisture reserves were good and amounted to more than $150 \mathrm{~mm}$. The conditions for realization of the varieties' potential were acceptable.

In all experimental variants, a complex of soil treatments aimed at combating weeds and preserving soil moisture was carried out: presowing cultivation and harrowing. Without any treatment, the yield of chickpeas was $10.5 \mathrm{c} /$ ha and of peas was $15.3 \mathrm{c} / \mathrm{ha}$. The treatment of crops with a physiologically active humic preparation makes it possible to slightly increase the yield by $1.0-1.9 \mathrm{c} / \mathrm{ha}$, and peas showed a higher responsiveness to the humic preparation. However, the increase in both crops did not exceed the LSD value.

The use of the herbicide prometrine and the insecticide dimethoate allowed us to save an additional $20 \%$ of the legume yield. However, the herbicide is aimed at combating both 
monocotyledonous and dicotyledonous weeds; therefore, it is used for soil cultivation before emergence, and the dose of its application on heavy loamy soils is slightly higher. Dimethoate is very toxic and can strongly inhibit vegetative plants. The additional application of a humic preparation in a tank mixture reduced the stress load, while the increase in yield increased up to $30 \%$.

The use of mineral fertilizers and the increased supply with nutrients allowed us to increase the productivity of chickpea by $56 \%$ compared to control and to obtain a yield of $19.5 \mathrm{c} / \mathrm{ha}$, and on peas, respectively, 52.2\% and $27.1 \mathrm{c} / \mathrm{ha}$. Without the use of any preparations to protect leguminous crops, the yield of chickpea, even with an average level of mineral nutrition, was only $12.5 \mathrm{c} /$ ha $(2 \mathrm{c} /$ ha more compared to the control without fertilizers), and on peas, $17.8 \mathrm{c} /$ ha (by $2.5 \mathrm{c} / \mathrm{ha}$ ).

In 2020, during the growing season of peas and chickpeas, the temperature and moisture conditions were dry (hydrothermal quotient 0.54 ). In some decades, there was a complete absence of precipitation. During the period of active vegetation (March-May), the amount of precipitation was $66.2 \mathrm{~mm}$, which is 2 times less than the average long-term value $(135 \mathrm{~mm})$, but about $80 \%$ of precipitation fell on May. Additionally, the reserves of productive moisture in the $0-100-\mathrm{cm}$ layer during sowing were about $100 \mathrm{~mm}$, which is estimated as average. Therefore, the yield on the control variant was lower than in 2019; nevertheless, these conditions made it possible to unleash the potential of the leguminous crop varieties, and the decrease in yield was small. Without the use of any protective agents, the chickpea yield was $9.1 \mathrm{c} / \mathrm{ha}$, and for the peas it was $11.7 \mathrm{c} / \mathrm{ha}$. It is known that humic fertilizers and preparations are more effective under extreme conditions [34]. In our experiment, this was confirmed: In less favorable weather conditions in 2020, the treatment of crops with a physiologically active humic preparation made it possible to significantly increase the yield and obtain a higher increase in control than in 2019: 3.0-3.8 c/ha. The 2020 study also showed high efficacy in the use of chemicals. The use of a chemical protection system using prometrine and dimethoate allowed us to save $17.6 \%$ of the yield of chickpea and $9.6 \%$ of the yield of peas as compared to the control.

The toxic load from the used chemical protection products in 2020 manifested itself much more strongly than in 2019, when the effectiveness was 19.0 and $20.9 \%$, respectively. This is due to the fact that insecticide treatments were carried out in the first ten-day period of June, when the budding phase began; during this period the average daily temperature was $+21^{\circ} \mathrm{C}$, and in the daytime the temperature reached $+32{ }^{\circ} \mathrm{C}$.

At elevated ambient temperatures, when plants are stressed, the phytotoxic effect of dimethoate is more pronounced. Yellowing of the plants, curvature of the stem, and delay in development were observed. When the biologically active humic preparation was applied, the negative effect of dimethoate smoothed out, and this allowed us to save $61.5 \%$ of the chickpeas' yield compared to the control. On peas, this value was $54.7 \%$, respectively. The efficiency of chickpeas is higher since this crop is more drought tolerant.

With an increase in the level of mineral nutrition, the productivity of plants increases and the same pattern remains. When using dimethoate, the increase in yield was the smallest. It was $1.3 \mathrm{c} /$ ha for chickpeas and $1.8 \mathrm{c} /$ ha for peas. This corresponded to 11.6 and $13.3 \%$ compared to the control. When a humic preparation was used together with chemical protection agents, the effectiveness of the latter was increased by reducing the toxic effect on vegetative plants.

In 2021, despite more favorable weather conditions, the patterns remained approximately the same. The yield was slightly higher for both chickpeas and peas in all variants than in the extremely dry 2020. In the variants with the humic preparation, the increase was higher in comparison with the control and the background by a statistically significant value. Insecticides showed a tendency to a decrease yield compared to the control variant; however, the addition of a humic preparation to the mixture completely removed this stress effect, and this effect was more pronounced on peas. 


\subsection{The Influence of a Humic Preparation on the Structure of Calcic Chernozem}

The structural condition of the soil is an important factor in soil fertility. The distribution of soil aggregates in the experimental variants without applying mineral fertilizers and with mineral fertilizers (Figure 1) under the chickpea indicates positive dynamics of the structural coefficient. There is a decrease in the proportion of the blocky fraction and an increase in the total amount of agronomically valuable aggregates.

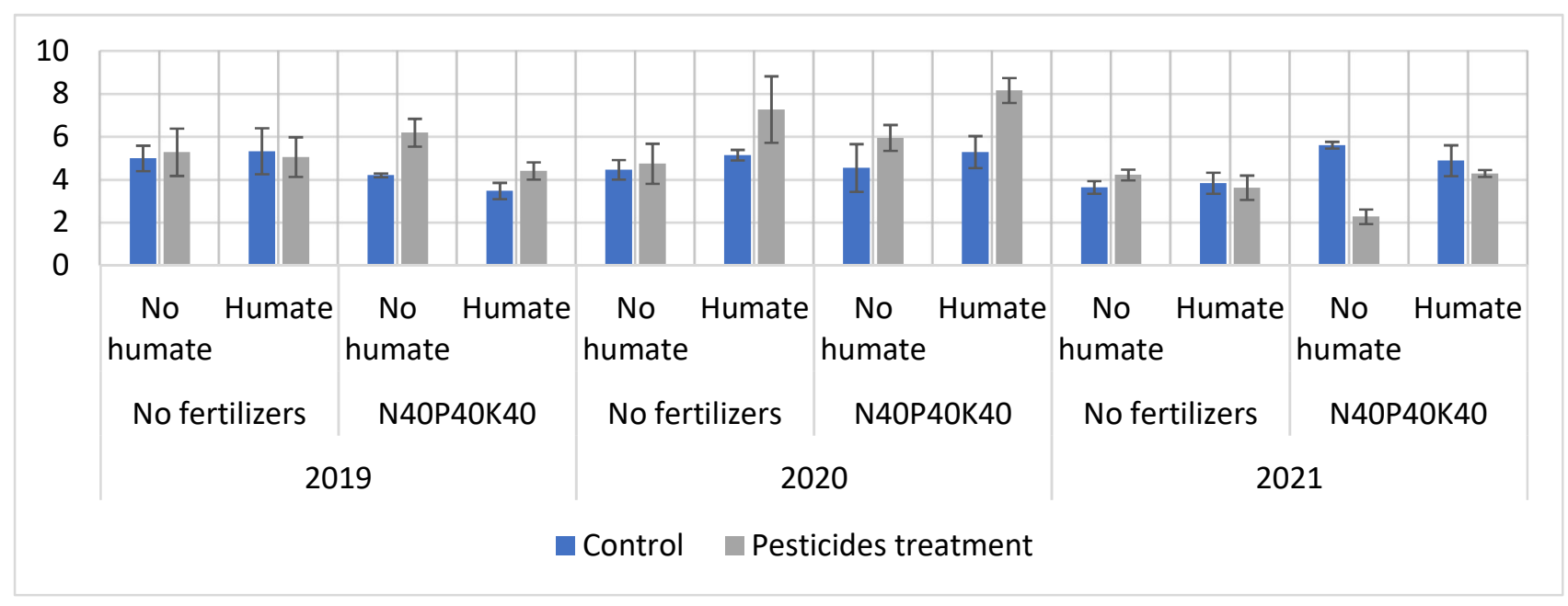

Figure 1. Dynamics of the structural coefficient in Calcic Chernozem under chickpea with the application of mineral fertilizers and a humic preparation on variants with and without pesticides.

In the control variant, foliar treatment of chickpea plants with a humic preparation did not affect the ratio of structural fractions. The inclusion of a humic preparation in the tank mixture with pesticides was accompanied by an increase in the structural coefficient on plots with mineral fertilizers. In 2020, this pattern was more pronounced and manifested on unfertilized plots as well. This is due to less favorable weather conditions of the year. In extreme weather conditions, the increased efficiency of the humic preparation in relation to yield had a favorable effect on the state of the soil structure: The ratio between agronomically valuable and agronomically ballast fractions increased. Moreover, in 2020 this beneficial effect of the humic preparation was more pronounced in the variants in which no mineral fertilizer was applied, and the plant nutrition was worse.

In the favorable year in terms of moisture (2021), the structural coefficient was significantly lower than in previous years of research. However, the effect of pesticides and the humic preparation on this indicator was similar, while mineral fertilizers contributed to a decrease in the structural coefficient value by a statistically significant value. The humic preparation reduced the negative effect of mineral fertilizers on the structure index, but the dispersing effect of the chemicals was not completely neutralized.

The ability of the structure to withstand the destructive action of water characterizes the ability of the soil to provide the root systems of plants with nutrients and moisture due to a stable relationship between phases. Therefore, when studying the structure of the soil, the determination of its water resistance is mandatory. The results obtained (Figure 2) indicated that the content of waterproof aggregates was lower on the plots with the application of mineral fertilizers. In 2019, the application of humic preparation decreased the content of water-resistant aggregates, while the treatment of plants with pesticides had little effect. In 2020, which was extreme in terms of aridity, the total content of water-resistant aggregates increased significantly after the application of the humates, but, again, the treatment of plants with pesticides had little effect on this indicator. 


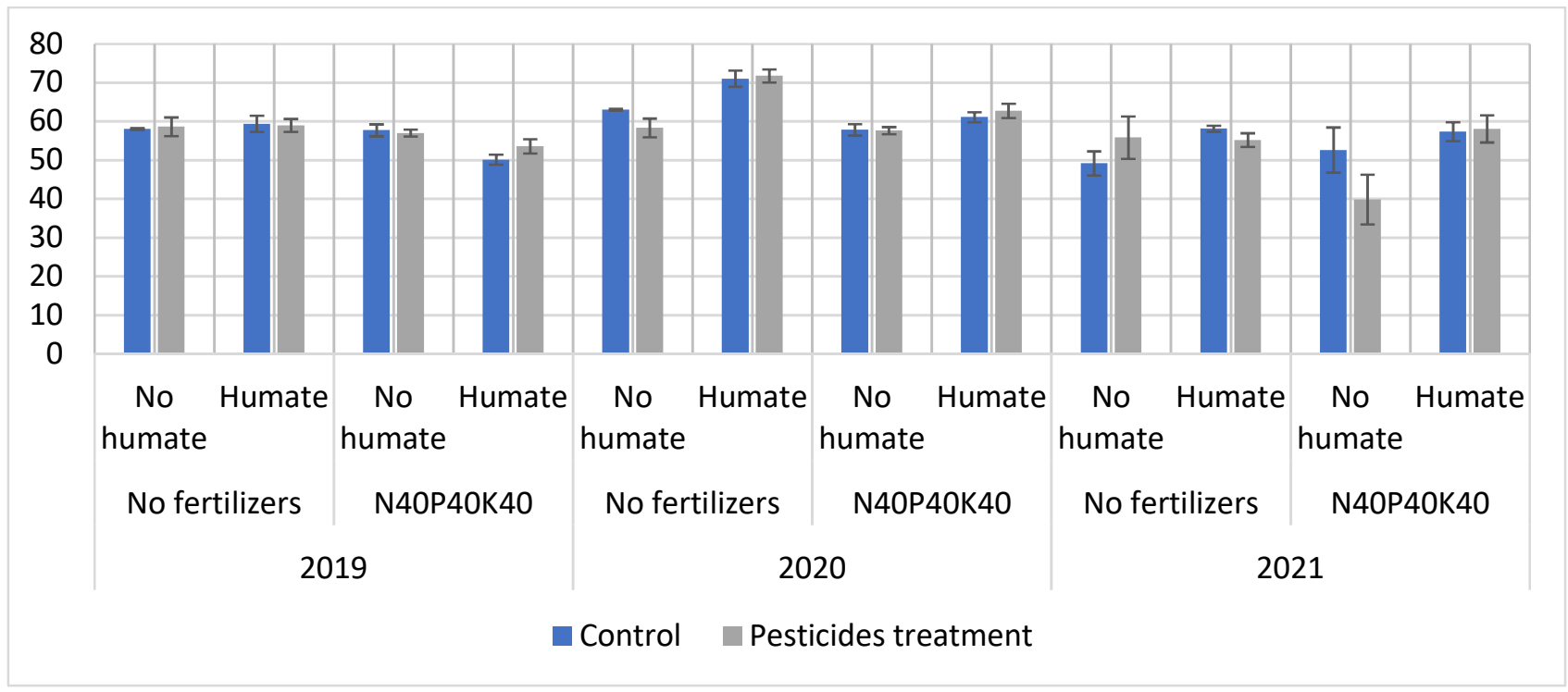

Figure 2. Dynamics of the distribution of water-resistant soil aggregates (\%) in Calcic Chernozem under chickpea with the application of mineral fertilizers and a humic preparation on experimental variants with and without pesticides.

In the experimental plot, where the peas were sown (2019), the soil was initially characterized by a less favorable ratio between the structural units; hence, the lower values of the structural coefficient and the content of water-resistant fractions were observed (Figure 3).

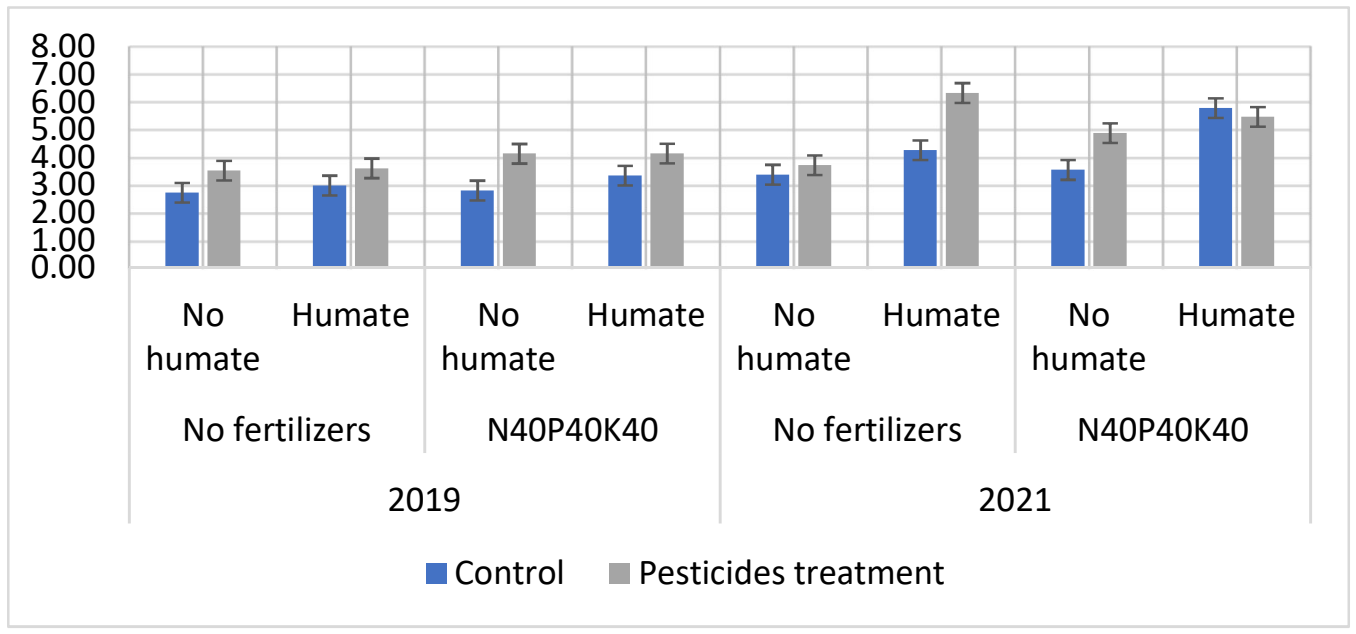

Figure 3. The influence of a humic preparation on the structure of Calcic Chernozem under peas.

The use of a humic preparation was accompanied by an increase in the structural coefficient both in the control and when using mineral fertilizers. The use of pesticides in all variants contributed to a significant improvement in the ratio between agronomically valuable and agronomically non-valuable aggregates, and the addition of a humic preparation to the tank mixture on peas had no effect on this indicator.

The water resistance of the soil structure in the control variants increased with the use of a humic preparation, while the pesticides mitigated this effect (Figure 4). On the other hand, in the variants with mineral fertilization, pesticides promoted an increase in the water resistance of structural aggregates, regardless of the presence of humates in the tank mixture. 


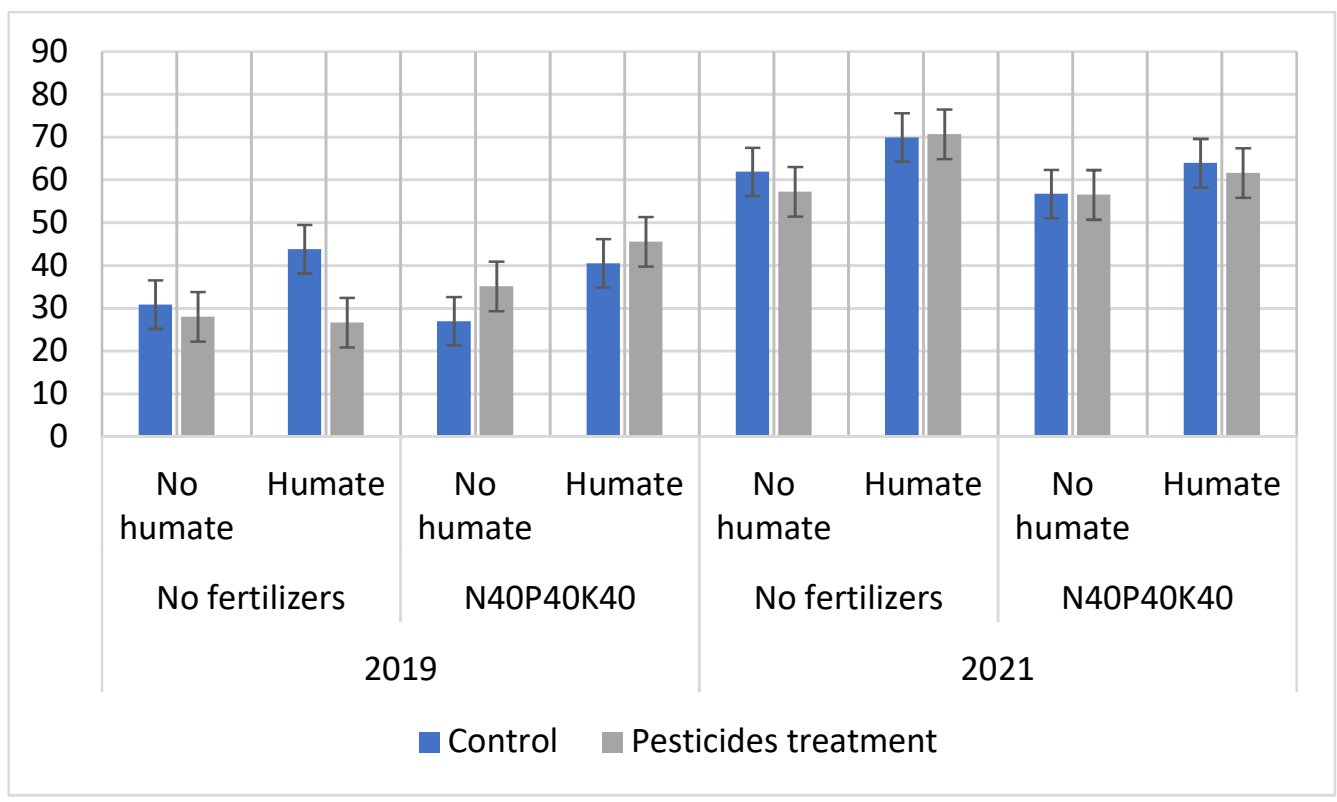

Figure 4. Influence of a humic preparation on the distribution of water-resistant soil aggregates in Calcic Chernozem under peas.

Thus, if a reliably pronounced positive effect of the humic preparation on the soil structure was obtained on chickpeas, especially on variants with the use of chemical protection, then on peas this effect was observed only on variants without chemical protection. The water resistance of structural aggregates under different crops also changed in different ways. Under the chickpea, the humic preparation decreased the number of water-resistant aggregates on fertilized variants and had no effect without fertilization. In contrast, under the peas there was an increase in water resistance in both unfertilized and fertilized variants.

\subsection{The Influence of the Humic Preparation on the Microbiological Activity of Calcic Chernozem}

The results of numerous studies have shown that, among a large number of factors in the formation of agronomically valuable aggregates with a diameter of more than $1 \mathrm{~mm}$, the leading role belongs to plants or, rather, to their roots. The mucus secreted by the root tips changes the solubility of the humic substances in the soil. The amount of dissolved organic carbon in Chernozem previously exposed to root exudates increases by $40.4 \%$ [35]. The mucus of the root end, containing polysaccharides, phenols, amino acids, and organic acids, wets the soil aggregates in direct contact with it. Cations of di- and polyvalent metals of the soil with the help of carboxyl and hydroxyl groups of polysaccharides, amino acids, and carboxylic acids of the mucus of the root endings are bound into complex compounds. The aggregates treated with mucus soon find themselves in the zone of root hairs, and active absorption of nutrients occurs. It was found that the share of plants in the formation of the most valuable structural aggregates of the soil is about $70 \%$, and the share of other factors is slightly more than 30\% [36]. Among the agricultural plants, the most pronounced effect on the physical properties of the soil is provided by solid-planted crops with a highly developed root system. The formation of the roots of the subsoil layer also depends on the depth of the rhizosphere development [37]. The decomposition of plant residues, the formation of the structure, and its water resistance are closely related to the content of microbial exopolysaccharides [38]. At the same time, the introduction of additional mineral nitrogen reduced the water resistance of aggregates over time due to the use of polysaccharides by microorganisms. Meanwhile, polysaccharides, as has been repeatedly pointed out in the literature, play an important role in the formation of the structure. The nuclei of microaggregates can be colonies of microorganisms that form capsules form their polysaccharide secretions, to which clay particles are attracted and attached. The 
clay shell forms a protective coating that prevents the decomposition of organic matter contained under such a shell. In parallel with the formation of aggregates, a pore space is formed between and within the aggregates. That is why, in our experiment, the number of microorganisms was controlled and the soil was sampled directly from the rhizosphere zone of plants. It turned out that different groups of microorganisms react differently to the treatment of plants with pesticides and a humic preparation, as well as the introduction of mineral fertilizers into the soil (Tables 6 and 7). Moreover, this reaction was significantly influenced by the weather conditions of the growing season. In the year 2019, favorable for the growing season of chickpea, on the control, the treatment of chickpea plants with a humic preparation of the groups of copiotrophic and prototrophic bacteria did not show a stable reaction. At the same time, in the extremely dry 2020, both groups showed a significant increase in numbers under the influence of this technique, especially when the humic preparation was applied in a tank mixture with pesticides.

Table 6. The influence of a humic preparation on the number of copiotrophic bacteria in Calcic Chernozem under chickpeas.

\begin{tabular}{cccc}
\hline $\begin{array}{c}\text { Experimental } \\
\text { Variant }\end{array}$ & Before Treatment & After Treatment & Change in Numbers, \% \\
\hline & \multicolumn{2}{c}{$\mathbf{2 0 1 9}$} \\
\hline C & $24.36 \pm 4.57$ & $55.56 \pm 0.52$ & $+128^{*}$ \\
C + H & $12.57 \pm 6.34$ & $57.33 \pm 20.29$ & $+356^{*}$ \\
CF & $20.07 \pm 3.68$ & $22.86 \pm 0.74$ & +14 \\
CF + H & $11.92 \pm 6.18$ & $36.00 \pm 12.33$ & $+202^{*}$ \\
CHF & $24.40 \pm 2.93$ & $38.64 \pm 2.71$ & +58 \\
CHF + H & $19.21 \pm 2.61$ & $49.01 \pm 7.93$ & $+155^{*}$ \\
& & 2020 & +22 \\
C & $16.69 \pm 6.65$ & $20.41 \pm 4.41$ & +34 \\
C + H & $37.19 \pm 5.06$ & $54.57 \pm 3.40$ & $+633^{*}$ \\
CF & $29.16 \pm 2.00$ & $39.00 \pm 5.06$ & $+53^{*}$ \\
CF + H & $17.40 \pm 2.98$ & $28.37 \pm 3.19$ & $+139 *$ \\
CHF & $29.44 \pm 3.88$ & $44.95 \pm 5.10$ & \\
CHF + H & $21.93 \pm 3.03$ & $52.35 \pm 4.42$ & \\
\hline
\end{tabular}

* The change is statistically significant $(p<0.05$. Supplementary Tables S1 and S2).

Table 7. The influence of a humic preparation on the number of prototrophic bacteria in Calcic Chernozem under chickpeas.

\begin{tabular}{cccc}
\hline $\begin{array}{c}\text { Experimental } \\
\text { Variant }\end{array}$ & Before Treatment & After Treatment & Change in Numbers, \% \\
\hline \multicolumn{3}{c}{$\mathbf{2 0 1 9}$} \\
\hline C & $73.32 \pm 13.81$ & $48.96 \pm 5.59$ & -33 \\
C + H & $61.94 \pm 9.86$ & $40.06 \pm 3.99$ & -35 \\
CF & $59.26 \pm 10.15$ & $27.88 \pm 3.30$ & $-53^{*}$ \\
CF + H & $61.63 \pm 7.68$ & $42.97 \pm 9.43$ & -30 \\
CHF & $57.33 \pm 13.89$ & $37.60 \pm 5.01$ & -34 \\
CHF + H & $60.38 \pm 8.26$ & $51.19 \pm 13.36$ & -15 \\
\hline & & 2020 & $+74^{*}$ \\
C & $26.78 \pm 5.51$ & $46.50 \pm 8.21$ & $+64^{*}$ \\
C + H & $62.14 \pm 5.14$ & $71.07 \pm 9.81$ & +59 \\
CF & $34.09 \pm 3.53$ & $55.89 \pm 10.02$ & $+56^{*}$ \\
CF + H & $30.44 \pm 3.66$ & $48.27 \pm 7.74$ & $+175^{*}$ \\
CHF & $39.97 \pm 3.07$ & $62.42 \pm 9.71$ & \\
CHF + H & $28.13 \pm 0.67$ & $77.33 \pm 5.40$ & \\
\hline
\end{tabular}

* The change is statistically significant $(p<0.05$. Supplementary Tables S1 and S2). 
The number of copiotrophic bacteria changed significantly on the variants with plant treatment with humic preparation and pesticides both in 2019 and in 2020. In both cases, in all variants of the experiment, an increase in the number of this group of bacteria was observed. This increase can be associated with the development of the root system of chickpea and active root exudation, which increases the amount of readily available organic matter in the rhizosphere soil. However, upon the application of humates, the increase in the number of bacteria from the beginning to the end of the experiment was many times greater. As for the influence of the conditions prevailing in different years, it can be noted that the humate treatment had a stronger effect on the abundance of copiotrophs in 2019, which was more optimal in terms of moisture and the positive effect of the biologically active compound on plant root system development could be fully implemented.

For the prototrophic bacteria, the opposite dynamics of abundance was observed in different years of the experiment. In 2019, all variants of the experiment showed an insignificant decrease in the number of bacteria after treatment, while, in 2020, an increase was observed in the most variants. At the same time, in 2020, in the variants without chemical treatment, a significant increase in the number of bacteria was observed in the variants that were not treated with humates, and only in the variant with the combined use of pesticides and humic preparation an increase in the numbers was significant and as high as $175 \%$.

Actinomycetes, spore-forming bacteria, and soil fungi showed a different reaction to the introduction of the humic preparation into the technological scheme. In 2019, there was steady, negative dynamics of the number of actinomycetes for all variants of the experiment, which may be associated with high competition with other groups of bacteria for available ecological niches. In 2020, the number of actinomycetes was higher, since these microorganisms are well adapted to drought. Nevertheless, in general, changes in the number of actinomycetes did not reach the level of statistically significant differences.

As for the spore-forming bacteria, in 2019 this group of microorganisms showed a stable abundance and did not react vividly to the experimental conditions. However, in 2020, a statistically significant increase in the number of spore-forming bacteria was observed after the treatment of chickpea plants. The use of humates had a stimulating effect on the number of this group of bacteria only in the variant with mineral fertilizers.

Soil fungi also showed very different population dynamics between the years of the experiment: In 2019, an increase was observed more often and, in 2020, their number decreased by the end of the experiment (Table 8).

Thus, the copiotrophic bacteria turned out to be the most indicative group of microorganisms, in relation to the experimental conditions, while the reaction of the other groups of microorganisms was largely associated with abiotic factors such as differences in temperature and humidity regimes that developed in different years of the experiment. Biotic connections within the microbial community, such as competition for substrate and niches for colonization, also played a significant role.

Due to the complex reaction of the microbial community to experimental conditions, a method for reducing the dimensionality of the data, the principal component analysis (PCA), was used to assess the relationship of microbiological indicators with data on the soil structure and water resistance of the soil aggregates. The analysis results are shown in Figure 5. 
Table 8. The influence of the humic preparation on the number of actinomycetes, spore-forming bacteria, and soil fungi under chickpeas.

\begin{tabular}{|c|c|c|c|c|}
\hline \multirow{3}{*}{$\begin{array}{l}\text { Experimental } \\
\text { Variant }\end{array}$} & $\begin{array}{c}\text { Number, } \\
\text { million CFU/g }\end{array}$ & $\begin{array}{l}\text { Change in } \\
\text { Number, \% }\end{array}$ & $\begin{array}{c}\text { Number, } \\
\text { million CFU/g }\end{array}$ & $\begin{array}{l}\text { Change in } \\
\text { Number, \% }\end{array}$ \\
\hline & \multicolumn{4}{|c|}{ Actinomycetes } \\
\hline & \multicolumn{2}{|c|}{2019} & \multicolumn{2}{|c|}{2020} \\
\hline $\mathrm{C}$ & $3.26 \pm 0.43$ & -11 & $3.60 \pm 0.34$ & +16 \\
\hline $\mathrm{C}+\mathrm{H}$ & $3.01 \pm 0.24$ & -24 & $3.77 \pm 0.56$ & -25 \\
\hline $\mathrm{CF}$ & $3.02 \pm 1.17$ & -35 & $4.12 \pm 0.90$ & -14 \\
\hline $\mathrm{CF}+\mathrm{H}$ & $1.44 \pm 0.21$ & $-73 *$ & $4.99 \pm 0.24$ & +31 \\
\hline $\mathrm{CHF}$ & $2.08 \pm 0.21$ & -45 & $3.21 \pm 0.97$ & -63 \\
\hline \multirow[t]{2}{*}{$\mathrm{CHF}+\mathrm{H}$} & $2.08 \pm 0.21$ & -17 & $2.03 \pm 0.17$ & $-63 *$ \\
\hline & \multicolumn{4}{|c|}{ Spore-forming bacteria } \\
\hline $\mathrm{C}$ & $3.44 \pm 0.22$ & +11 & $3.32 \pm 0.44$ & $+73 *$ \\
\hline $\mathrm{C}+\mathrm{H}$ & $3.15 \pm 0.33$ & +32 & $2.88 \pm 0.36$ & -10 \\
\hline $\mathrm{CF}$ & $4.48 \pm 0.67$ & +25 & $2.73 \pm 0.28$ & +34 \\
\hline $\mathrm{CF}+\mathrm{H}$ & $3.64 \pm 0.27$ & +24 & $4.66 \pm 0.25$ & $+79 *$ \\
\hline $\mathrm{CHF}$ & $3.32 \pm 0.39$ & -9 & $3.73 \pm 0.43$ & $+41 *$ \\
\hline \multirow[t]{2}{*}{$\mathrm{CHF}+\mathrm{H}$} & $3.43 \pm 0.70$ & -12 & $4.22 \pm 0.25$ & $+32 *$ \\
\hline & \multicolumn{4}{|c|}{ Soil fungi, thousand CFU/g } \\
\hline $\mathrm{C}$ & $96.88 \pm 16.20$ & $+202 *$ & $125.65 \pm 8.43$ & -20 \\
\hline $\mathrm{C}+\mathrm{H}$ & $59.43 \pm 12.64$ & +40 & $86.54 \pm 11.02$ & -23 \\
\hline $\mathrm{CF}$ & $56.99 \pm 4.29$ & -12 & $128.42 \pm 21.40$ & +31 \\
\hline $\mathrm{CF}+\mathrm{H}$ & $114.19 \pm 18.61$ & +25 & $51.43 \pm 18.13$ & $-64 *$ \\
\hline $\mathrm{CHF}$ & $95.04 \pm 7.88$ & +62 & $52.08 \pm 6.05$ & -32 \\
\hline $\mathrm{CHF}+\mathrm{H}$ & $123.92 \pm 21.32$ & +205 * & $50.12 \pm 4.77$ & -49 \\
\hline
\end{tabular}

* The change is statistically significant ( $p<0.05$. Supplementary Tables S1 and S2).

2019

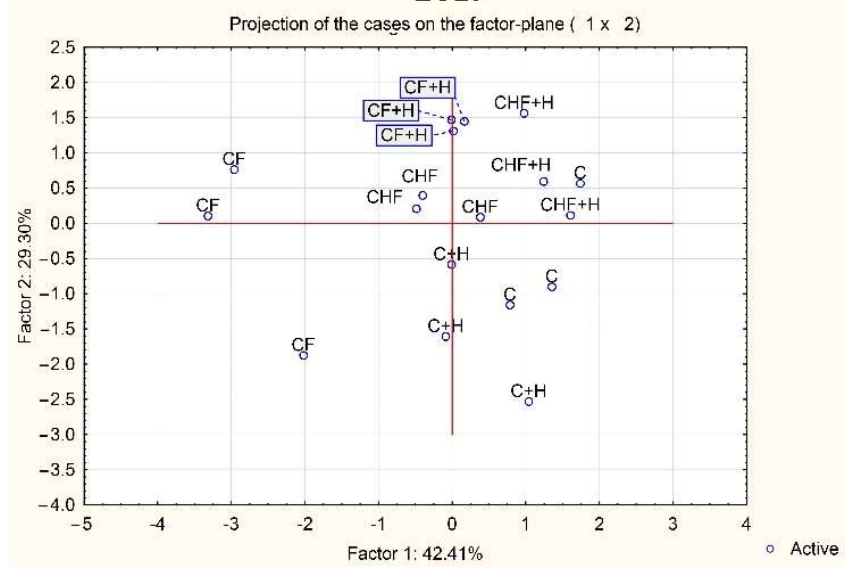

2020

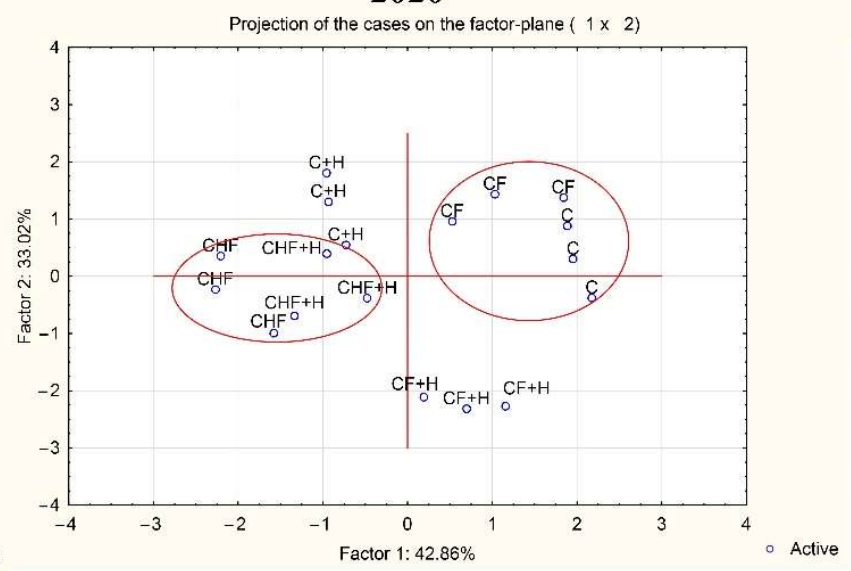

Figure 5. Position of the experimental variants in the plane of the first two principal components.

It can be clearly seen from the diagram that in 2019 the two principal components extracted during the analysis of the data set on the abundance of the microbial community are weakly related to the use of humates in the technology of chickpea cultivation. At the same time, it is possible to note the relationship of the principal component 2 , which explains $29.3 \%$ of the total dispersion with the use of mineral fertilizers.

In 2020, more unfavorable in terms of weather conditions, the control variants were clearly separated from the variants when the pesticides were used by the principal component 1 , which explains $42.86 \%$ of the observed variance, while the variants with the addition of humates occupy an intermediate position, which indicates their protective effect. 
The factor loadings of the microbial community abundance parameters used in PCA are shown in Table 9.

Table 9. The correlations between principal components from microbial community analysis and soil structural characteristics.

\begin{tabular}{|c|c|c|c|c|c|c|}
\hline \multirow{2}{*}{ Variable } & \multicolumn{3}{|c|}{2019} & \multicolumn{3}{|c|}{2020} \\
\hline & Factor 1 & Factor 2 & Factor 3 & Factor 1 & Factor 2 & Factor 3 \\
\hline Copiotrophic & 0.764 & -0.407 & 0.052 & -0.835 & 0.343 & 0.199 \\
\hline Prototrophic & 0.807 & 0.222 & -0.323 & -0.805 & 0.294 & 0.336 \\
\hline Actinomycetes & -0.041 & -0.845 & -0.483 & 0.446 & -0.396 & 0.800 \\
\hline Spore-forming & -0.711 & 0.397 & -0.466 & -0.247 & -0.940 & -0.109 \\
\hline Fungi & 0.616 & 0.615 & -0.212 & 0.734 & 0.637 & 0.073 \\
\hline
\end{tabular}

It can be seen that the microbial parameters demonstrated stronger factor-variable correlations in 2020, resulting in better separation of the experimental variants. The most significant difference was observed for spore-forming bacteria and actinomycetes, which may be attributed to their adaptation to reduced humidity.

Subsequently, a correlation analysis of the identified principal components with data on the structure of the soil and its water resistance was carried out (Table 10).

Table 10. The correlations between principal components from microbial community analysis and soil structural characteristics.

\begin{tabular}{cccc}
\hline & Structure & Water Resistance \\
\hline & & $\mathbf{2 0 1 9}$ & \\
\hline PC1 & 0.116 & -0.003 \\
PC2 & $-0.505^{*}$ & $-0.787^{*}$ \\
\hline & & 2020 & \\
\hline PC1 & $-0.643^{*}$ & & 0.279 \\
PC2 & -0.455 & & 0.241 \\
\hline
\end{tabular}

* Correlation is significant at $p<0.05$.

The presented data demonstrate that, in 2019, there was a significant negative correlation between PC2 and indicators of soil structure, as well as a strong correlation with indicators of its water resistance, which reflects the negative effect of mineral fertilizers on the structure of the soil and their effect on the composition of the microbial community and the intensity of mineralization of readily available soil organic matter. In 2020, under the conditions of insufficient moisture, there was no relationship between the identified factors and the water resistance of soil aggregates, but a correlation with PC1 was revealed, reflecting the effect of pesticides on the soil microbial community and the protective effect of humates when used in tank mixtures.

In the experiment, the total humus content was also controlled. In the fertilized experimental variants, humus content varied slightly, and on variants without mineral fertilizers, the content of this indicator varied: It could either increase or decrease in comparison with the control, by a statistically insignificant value (Table 11). In general, the dynamics of the humus content was insignificant and did not correlate with the number of agronomically valuable aggregates. 
Table 11. The content of humus in the arable layer of carbonate chernozem according to the variants of the experiment with mineral fertilizer and humic preparation under chickpeas.

\begin{tabular}{|c|c|c|c|c|c|c|c|c|c|c|c|c|}
\hline \multirow{3}{*}{ Variant } & \multicolumn{4}{|c|}{2019} & \multicolumn{4}{|c|}{2020} & \multicolumn{4}{|c|}{2021} \\
\hline & \multicolumn{2}{|c|}{ No Fertilizers } & \multicolumn{2}{|c|}{ N40P40K40 } & \multicolumn{2}{|c|}{ No Fertilizers } & \multicolumn{2}{|c|}{ N40P40K40 } & \multicolumn{2}{|c|}{ No Fertilizers } & \multicolumn{2}{|c|}{ N40P40K40 } \\
\hline & 1 & 2 & 1 & 2 & 1 & 2 & 1 & 2 & 1 & 2 & 1 & 2 \\
\hline $\mathrm{C}$ & 3.83 & - & 3.83 & - & 3.9 & - & 3.9 & - & 3.82 & - & 3.78 & - \\
\hline $\mathrm{H}$ & 3.74 & -0.09 & 3.74 & -0.09 & 4.1 & +0.2 & 3.9 & 0 & 4.00 & +0.18 & 3.87 & 0.09 \\
\hline $\mathrm{CH}$ & 3.88 & +0.05 & 3.88 & +0.05 & 4.0 & +0.1 & 3.9 & 0 & 3.70 & -0.12 & 3.58 & -0.20 \\
\hline $\mathrm{CH}+\mathrm{H}$ & 3.76 & -0.07 & 3.76 & -0.07 & 4.4 & +0.5 & 3.9 & 0 & 3.95 & +0.13 & 3.76 & -0.02 \\
\hline $\mathrm{LSD}_{05}$ & & 0.02 & & 0.02 & & 0.1 & & 0 & & 0.1 & & 0.02 \\
\hline
\end{tabular}

1 , humus content, $\% ; 2$, difference from the control, $\%$.

\section{Discussion}

The soil acquired an agronomically valuable structure due to the cementation of its individual parts with humus, which was formed from decomposing organic compounds due to the vital activity of microorganisms.

The accumulation of substances that contribute to structuring in the soil occurred with the assistance of microorganisms: fungi and bacteria. The emergence of these organic compounds from decomposing plant and animal remains with the participation of soil microorganisms was noted as early as the first half of the 20th century in works that emphasized the role of microorganisms in structure formation [39-41].

It is known that the redox conditions on the surface of the aggregate and inside it are different; therefore, the composition of microorganisms, the set of enzymes, and the nature of the processes will differ. Facultative anaerobic organisms settle inside the aggregate, while aerobic microorganisms colonize the surface of the structural units [42]. As a result, the processes of transformation of organic compounds on the surface of the unit and inside it will proceed in different ways. Therefore, according to I.V. Kovalev et al. [43,44], on the surface of aggregates (under oxidizing conditions), a smaller amount of lignin oxidation products and a higher degree of its oxidation are observed while inside the aggregate, in a reducing environment, lignin destruction slows down and its accumulation occurs. In the case of the relationship between the structural state of the soil and biotic factors, there are mechanisms and processes of physical (non-humification) stabilization of organic matter. The essence of this process lies in the spatial inaccessibility of biogenic compounds to microorganisms and enzymes, which is directly related to the conditions of moisture and gas exchange, which are directly affected by the structural composition of the soil [45]. The considered phenomenon is the basic mechanism of the formation of micro- and macroaggregates in the soil.

V.R. Williams [46], known as the theorist and propagandist of the grass-growing system of agriculture, drew attention to the fact that the (granular) structure of the soil prevails in the root zone of plants. The formation of soil aggregates involves the roots themselves (by their root secretions) and microorganisms living inside them, which produce a specific substance, "fresh" (by Williams' definition) humus, but the use of pesticides inhibits the physiological processes of not only pests but also the useful part of the biota. To assess the dynamics of agrophysical properties, the content of water-resistant aggregates turned out to be quite highly informative under peas and not very informative under chickpeas.

Nevertheless, even under the chickpea, some patterns were noted. Therefore, before the treatment of crops with a tank mixture of pesticides and a humic preparation, the content of water-resistant aggregates with a diameter of $5 \mathrm{~mm}$ to $0.25 \mathrm{~mm}$ varied on experimental plots from 48.4 to $65.4 \%$, which corresponded to gradations from satisfactory to good when assessing the structural state according to the Bakhtin-Dolgova scale. During the growing season, natural destructive processes occur in the soil, aimed at the destruction of agronomically valuable aggregates. 
The application of mineral fertilizers enhances degradation processes, which can primarily be associated with the dispersing effect of the cations included in the fertilizer composition on colloidal particles in the soil, from which elementary soil particles, microaggregates, and macroaggregates are subsequently formed [47]. Apparently, some fractions, namely, from $1 \mathrm{~mm}$ to $0.25 \mathrm{~mm}$, react more actively to the effect of mineral fertilizers. To confirm this assumption, it was necessary to pay attention to the variant " $\mathrm{C}+\mathrm{H}^{\prime}$, in which only a humic preparation was introduced. After treatment on this variant, the content of water-resistant aggregates was the highest, and the difference compared to the control was the most pronounced: $+6.05 \%$, with $\mathrm{LSD}_{0.05}=5.02$. Under peas, the effect of the humic preparation on the water resistance of aggregates was even more evident (Figure 3). Statistically significant differences in the content of water-resistant aggregates between the variants without treatment and with humate treatment were found not only in the control but also against the background of mineral fertilizers and in the variant with pesticides.

Pesticides, including herbicides and fungicides, due to their high toxicity in relation to plant communities, indirectly cause the degradation of the agrophysical properties of soils actively used in crop rotation, as evidenced by the high losses of water-resistant aggregates under the chickpea. The introduction of humic preparations allowed us to reduce the loss of an agronomically valuable structure.

The results of the principal components analysis clearly demonstrated the role of the microbial community in the maintenance of the soil structure and its water resistance during the cultivation of chickpea. In 2019, with a more favorable moisture regime, the distribution of the microbial community was associated with the use of mineral fertilizers, and in the fertilized variants, the structure indices were lower than in the control without fertilizers. It is known that polysaccharides of both plant and microbial origin are involved in maintaining the structure of the soil and its water resistance [48]. Chickpea actively secretes rhizodeposits, which allows it to actively transform the soil adjacent to the roots and withstand conditions of insufficient moisture [49]. Fertilization shifts the C:N ratio in the soil and this allows microorganisms to more efficiently mineralize readily available carbon compounds, including polysaccharides. The most active hydrolytics are the copiotrophic bacteria, and this group showed the greatest increase in numbers by the end of the experiment. In 2020, against the background of increased temperature and insufficient moisture, there was no connection between the structure and water-resistance coefficients with the use of mineral fertilizers, which can be associated with less favorable conditions for the mineralization process. However, this year the effect of pesticides on the soil microbial community and the protective effect of humates was manifested more clearly (Figure 5). Interestingly, at the same time, against the background of the use of pesticides, an increase in the soil structural quotient was observed and a significant correlation was noted with the principal component 1 extracted during the PCA analysis of the microbial community.

In our opinion, the increased content of agronomically valuable aggregates in the experimental variants with the use of pesticides can be associated with the suppression of the biochemical activity of microorganisms and a decrease in the rate of mineralization of soil organic matter, which is involved in maintaining the soil structure. At the same time, the total number of microorganisms in these variants did not decrease, since many rhizosphere bacteria are more or less resistant to the toxic effect of pesticides [50]. As for the positive effect of treatment with humates when used in tank mixtures with pesticides (Supplementary Tables S3 and S4), it can be associated with their stress-protective effect [16,51] as well as their ability to enhance root exudation [52], which creates opportunities for the synthesis of structure-forming substances by microorganisms in the rhizosphere soil.

It is important to emphasize that the humic preparation was used to treat plants; in this experiment, these substances were not introduced into the soil. Nevertheless, there was a pronounced positive effect not only on the yield of legumes but also on the number of microorganisms in the rhizosphere zone, as well as on the structural properties of the soil. This indicated the presence of a feedback between plant organisms and microorganisms of 
the root zone, resulting in an improvement of the soil properties, in particular, the state of its structure.

\section{Conclusions}

The results of the study showed that both the use of pesticides and humates have an indirect effect on the structure of the soil. At the same time, the key mediators of this influence are the biotic components of the agroecosystem, namely, the cultivated crop and the microbial community of the soil. It was found that in the cultivation of legumes, the application of mineral fertilizers had a negative effect on the structure of the soil, while, when using pesticides, the structure was preserved better by the end of the growing season. The revealed patterns can be associated with the activity of microorganisms participating in the hydrolysis of organic compounds that stabilize soil aggregates. The use of humates was more effective in case of unfavorable abiotic factors that developed in 2020. By reducing the pesticide load on plants, the addition of humates to the composition of tank mixtures made it possible to obtain higher yields for both chickpeas and peas. In addition to the effect on the yield, the use of a humic preparation on chickpeas improved the soil structure and water resistance, especially in the variants with chemical protection, and on the peas, this effect was noted only in the variants without chemical protection.

Thus, the introduction of humic preparations into the technological scheme for the cultivation of legumes seems to be expedient both from the point of view of the economic effect of increasing the yield and also from the point of view of increasing soil fertility and preserving the agronomically valuable structure in it.

Supplementary Materials: The following are available online at https:/ / www.mdpi.com/article/10 .3390 /agronomy11102053/s1, Table S1: The results of ANOVA for the numbers of bacteria in the soils of experimental plots in 2019 before and after the treatment, Table S2: The results of ANOVA for the numbers of bacteria in the soils of experimental plots in 2020 before and after the treatment, Table S3: The results of ANOVA for the structural quotient in the soils of experimental plots, Table S4: The results of ANOVA for the water-resistance quotient in the soils of experimental plots.

Author Contributions: Conceptualization, O.B. and A.G. (Andrey Gorovtsov); data curation, S.K. and V.L.; formal analysis, A.G. (Andrey Gorovtsov) and E.P. (Elena Polienko); funding acquisition, O.B. and A.K.; investigation, A.G. (Andrey Gorovtsov), V.L., and E.P. (Elena Polienko); methodology, A.G. (Artem Grinko) and E.P. (Elena Polienko); project administration, A.K.; resources, O.B. and A.G. (Artem Grinko); software, E.P. (Evgeny Patrikeev); supervision, O.B.; validation, A.G. (Artem Grinko) and E.P. (Evgeny Patrikeev); visualization, S.K. and E.P. (Evgeny Patrikeev); writing-original draft, O.B. and A.G. (Andrey Gorovtsov); writing-review and editing, A.G. (Andrey Gorovtsov) and E.P. (Elena Polienko). All authors have read and agreed to the published version of the manuscript.

Funding: The reported study was funded by the Federal budget (No. AAAA-A19-119052290027-4).

Institutional Review Board Statement: Not applicable.

Informed Consent Statement: Not applicable.

Data Availability Statement: Not applicable.

Conflicts of Interest: The authors declare no conflict of interest. The funders had no role in the design of the study; in the collection, analyses, or interpretation of data; in the writing of the manuscript; or in the decision to publish the results.

\section{References}

1. Kononova, M.M. Soil Organic Matter. Its Nature, Its Role in Soil Formation and in Soil Fertility, 2nd ed.; Pergamon Press: London, UK, 1966; p. 544.

2. Orlov, D.S. Soil Chemistry; Oxford \& IBH Publishing Co. Pvt. Ltd.: New Delhi, India, 1992; p. 402.

3. Stevenson, F.J. Humic Chemistry: Genesis, Composition, Reactions; John Wiley \& Sons: New York, NY, USA, $1994 ;$ pp. 34-41.

4. Pizzeghello, D.; Schiavon, M.; Francioso, O.; Vecchia, F.D.; Ertani, A.; Nardi, S. Bioactivity of Size-Fractionated and Unfractionated Humic Substances From Two Forest Soils and Comparative Effects on N and S Metabolism, Nutrition, and Root Anatomy of Allium sativum L. Front. Plant Sci. 2020, 11, 1203. [CrossRef] [PubMed] 
5. Nardi, S.; Pizzeghello, D.; Muscolo, A.; Vianello, A. Physiological effects of humic substances on higher plants. Soil Biol. Biochem. 2002, 34, 1527-1536. [CrossRef]

6. Tahir, M.M.; Khurshid, M.; Khan, M.Z.; Abbasi, M.K.; Kazmi, M.H. Lignite-derived humic acid effect on growth of wheat plants in different soils. Pedosphere 2011, 21, 124-131. [CrossRef]

7. Cordeiro, F.C.; Santa-Catarina, C.; Silveira, V.; De Souza, S.R. Humic acid effect on catalase activity and the generation of reactive oxygen species in corn (Zea mays). Biosci. Biotechnol. Biochem. 2011, 75, 70-74. [CrossRef] [PubMed]

8. Suzuki, N.; Koussevitzky, S.; Mittler, R.; Miller, G. ROS and redox signalling in the response of plants to abiotic stress. Plant Cell Environ. 2012, 35, 259-270. [CrossRef] [PubMed]

9. Canellas, L.P.; Olivares, F.L.; Aguiar, N.O.; Jones, D.L.; Nebbioso, A.; Mazzei, P.; Piccolo, A. Humic and fulvic acids as biostimulants in horticulture. Sci. Hortic. 2015, 196, 15-27. [CrossRef]

10. Perminova, I.V.; Hatfield, K. Remediation chemistry of humic substances: Theory and implications for technology. In The Use of Humic Substances to Remediate Polluted Environment: From Theory to Practice; Perminova, I.V., Hatfield, K., Hertkorn, N., Eds.; Science Series IV: Earth and Environmental Sciences; Springer: Dordrecht, The Netherlands, 2005; Volume 52, pp. 3-36.

11. Kalina, M.; Klučáková, M.; Sedláček, P. Utilization of fractional extraction for characterization of the interactions between humic acids and metals. Geoderma 2013, 207-208, 92-98. [CrossRef]

12. Stathi, P.; Deligiannakis, Y. Humic acid-inspired hybrid materials as heavy metal absorbents. J. Colloid Interface Sci. 2010, 351, 239-247. [CrossRef]

13. Bezuglova, O.S.; Gorbov, S.N.; Tischenko, S.A.; Shimko, A.E. Use of brown coal as a detoxifier of soils contaminated with heavy metals. J. Geochem. Exp. 2018, 184, 232-238. [CrossRef]

14. Kulikova, N.A.; Perminova, I.V. Sorption-desorption of atrazine on mineral-bound humic substances related to their structure. Fresenius Environ. Bull. 2007, 16, 1061-1068.

15. Tejeda-Agredano, M.-C.; Mayer, P.; Ortega-Calvo, J.-J. The effect of humic acids on biodegradation of polycyclic aromatic hydrocarbons depends on the exposure regime. Environ. Pollut. 2014, 184, 435-442. [CrossRef]

16. Bezuglova, O.S.; Gorovtsov, A.V.; Polienko, E.A.; Zinchenko, V.E.; Grinko, A.V.; Lykhman, V.A.; Dubinina, M.N.; Demidov, A. Effect of humic preparation on winter wheat productivity and rhizosphere microbial community under herbicide-induced stress. J. Soils Sediments 2019, 19, 2665-2675. [CrossRef]

17. Motta, F.L.; Santana, M.H.A. Production of humic acids from oil palm empty fruit bunch by submerged fermentation with Trichoderma viride: Cellulosic substrates and nitrogen sources. Biotechnol. Prog. 2013, 29, 631-637. [CrossRef] [PubMed]

18. García, A.; Berbara, R.; Farías, L.; Izquierdo, F.; Hernández, O.; Campos, R.; Castro, R. Humic acids of vermicompost as an ecological pathway to increase resistance of rice seedlings to water stress. Afr. J. Biotechnol. 2014, 11, 3125-3134.

19. Bezuglova, O.S.; Polienko, E.A.; Gorovtsov, A.V.; Lyhman, V.A.; Pavlov, P.D. The effect of humic substances on winter wheat yield and fertility of ordinary chernozem. Ann. Agrar. Sci. 2017, 15, 239-242. [CrossRef]

20. Pozdnyakov, L.A.; Stepanov, A.L.; Gasanov, M.E.; Semenov, M.V.; Yakimenko, O.S.; Suada, I.K.; Rai, I.N.; Shchegolkova, N.M Effect of Lignohumate on Soil Biological Activity on the Bali Island, Indonesia. Eurasian Soil Sci. 2020, 53, 653-660. [CrossRef]

21. Bronick, C.J.; Lal, R. Soil structure and management: A review. Geoderma 2005, 124, 3-22. [CrossRef]

22. Six, J.; Bossuyt, H.; Degryze, S.; Denef, K. A history of research on the link between (micro)aggregates, soil biota, and soil organic matter dynamics. Soil Tillage Res. 2004, 79, 7-13. [CrossRef]

23. Abiven, S.; Menasseri, S.; Chenu, C. The effects of organic inputs over time on soil aggregate stability-a literature analysis. Soil Biol. Biochem. 2009, 41, 1-12. [CrossRef]

24. Milanovskiy, E.Y.; Rusanov, A.M.; Shein, E.V. Dependence of aggregates water stability from the contents of hydrophilic and hydrophobic components in the organic matter of chernozems. Eurasian J. Soil Sci. 2013, 2, 102-106.

25. Shein, E.; Milanovskiy, E. Soil structure formation: Role of the soil amphiphilic organic matter. Biogeosystem Tech. 2014, 2, 182-190. [CrossRef]

26. Gonet, S.S.; Czachor, H.; Markiewicz, M. Organic Carbon and Humic Substances Fractions in Soil Aggregates. In Functions of Natural Organic Matter in Changing Environment; Springer: Dordrecht, The Netherlands, 2013; pp. 385-389.

27. Gümüsh, I.; Sheker, C. Influence of humic acid applications on soil physicochemical properties. Solid Earth Discuss. 2015, 7, 2481-2500. [CrossRef]

28. Lykhman, V.A.; Bezuglova, O.S.; Polienko, E.A.; Dubinina, M.N.; Naimi, O.I.; Patrikeev, E.S. Influence of humic preparations on the content of carbohydrates in structural aggregates and their water resistance. Sci. J. Russ. Res. Inst. Melior. Probl. 2020, 1, 154-168. (In Russian) [CrossRef]

29. Grekhova, I.V.; Kurtova, A.V.; Fedotova, O.V. The efficiency of foliar treatments of grain crops and potatoes with humic preparation Rostock. Int. J. Green Pharm. 2018, 12, 712-715.

30. Mineev, V.G.; Sychev, V.G.; Amelyanchik, O.A.; Bolysheva, T.N.; Gomonova, N.F.; Durynina, E.P.; Prizhukova, V.G. Workshop on Agrochemistry: Textbook, 2nd ed.; revised and additional. Academician of the Russian Academy of Agricultural Sciences; Mineev, V.G.-M., Ed.; Publishing house of Moscow State University: Moscow, Russia, 2001; p. 689. (In Russian)

31. Vadyunina, A.F.; Korchagina, Z.A. Methods for Studying the Physical Properties of Soils; Agropromizdat: Moscow, Russia, 1986; p. 416.

32. Zuberer, D.A. Recovery and enumeration of viable bacteria. In Methods of Soil Analysis: Part 2 Microbiological and Biochemical Properties; Wiley: Hoboken, NJ, USA, 1994; Volume 5, pp. 119-144. 
33. Siala, A.; Hill, I.R.; Gray, T.R.G. Populations of spore-forming bacteria in an acid forest soil, with special reference to Bacillus subtilis. Microbiology 1974, 81, 183-190. [CrossRef]

34. Jindo, K.; Olivares, F.L.; Malcher, D.J.P.; Sánchez-Monedero, M.A.; Kempenaar, C.; Canellas, L.P. From Lab to Field: Role of Humic Substances Under Open-Field and Greenhouse Conditions as Biostimulant and Biocontrol agent. Front. Plant Sci. 2020, 11, 426. [CrossRef]

35. Volkov, O.I. Influence of root secretions of germinating seeds of barley (Hordeum vulgare L.) on the qualitative and quantitative composition of organic components of the soil. J. Gen. Biol. 2010, 71, 359-368. (In Russian)

36. Vorobiev, S.A.; Shvarov, Y.V. Programs for Processing Geochemical Data on Microcalculators; Publishing House Nedra: Moscow, Russia, 1984; p. 102.

37. Pillai, U.P.; McGarry, D. Structure Repair of a Compacted Vertisol with Wet-Dry Cycles and Crops. Soil Sci. Soc. Am. J. 1999, 63, 201-210. [CrossRef]

38. Le Guillou, C.; Angers, D.A.; Maron, P.A.; Leterme, P.; Menasseri-Aubry, S. Linking microbial community to soil water-stable aggregation during crop residue decomposition. Soil Biol.Biochem. 2012, 50, 126-133. [CrossRef]

39. IodeГ, R.E.J. The effect of long-time cropping systems and tillage practices upon soil aggregation. Amer. Sos. Agroh. 1936, 28, 86-89.

40. Waksman, S.A.; Woodruff, H.B. The soil as a source of microorganisms antagonistic to disease-producing bacteria. J. Bacteriol. 1940, 40, 581. [CrossRef]

41. Li, Y.; Fang, F.; Wei, J.; Wu, X.; Cui, R.; Li, G.; Zheng, F.; Tan, D. Humic Acid Fertilizer Improved Soil Properties and Soil Microbial Diversity of Continuous Cropping Peanut: A Three-Year Experiment. Sci. Rep. 2019, 9, 12014. [CrossRef]

42. Verkhovtseva, N.V.; Kubarev, E.N.; Mineev, V.G. Agrochemical agents in maintaining the structure of the soil microbial community. Russ. Agric. Sci. 2007, 33, 100-102. [CrossRef]

43. Kovalev, I.V.; Kovaleva, N.O. The role of lignin phenols in organic-mineral interactions in soils. In Book of Abstract: 19th International Conference of Humus Substances and their Contribution to the Climate Change Mitigation; Bulgarian Humic Substances Society: Sofia, Bulgaria, 2018; pp. 120-121.

44. Semenov, V.M.; Lebedeva, T.N.; Pautova, N.B.; Khromychkina, D.P.; Kovalev, I.V.; Kovaleva, N.O. Relationships between the Size of Aggregates, Particulate Organic Matter Content, and Decomposition of Plant Residues in Soil. Eurasian Soil Sci. 2020, 53, 454-466. [CrossRef]

45. Sollins, P.; Homann, P.; Caldwell, B.A. Stabilization and destabilization of soil organic matter: Mechanisms and controls. Geoderma 1996, 74, 65-105. [CrossRef]

46. Williams, V.R. Strength and connectivity of soil structure. Pochvovedenie 1935, 5/6, 746-754. (In Russian)

47. Aleksandrova, L.N.; Nagy, T. On the nature of organomineral colloids and methods of their study. Pochvovedenie 1958, 10, 21-27. (In Russian)

48. Czarnes, S.; Hallett, P.D.; Bengough, A.G.; Young, I.M. Root-and microbial-derived mucilages affect soil structure and water transport. Eur. J. Soil Sci. 2000, 51, 435-443. [CrossRef]

49. Rabbi, S.M.; Tighe, M.K.; Knox, O.; Young, I.M. The impact of carbon addition on the organisation of rhizosheath of chickpea. Sci. Rep. 2018, 8, 18028. [CrossRef]

50. Ahemad, M.; Khan, M.S. Assessment of pesticide-tolerance and functional diversity of bacterial strains isolated from rhizospheres of different crops. Insight Microbiol. 2011, 1, 8-19. [CrossRef]

51. Taspinar, M.S.; Aydin, M.; Sigmaz, B.; Yildirim, N.; Agar, G. Protective role of humic acids against picloram-induced genomic instability and DNA methylation in Phaseolus vulgaris. Environ. Sci. Pollut. Res. 2017, 24, 22948-22953. [CrossRef] [PubMed]

52. Canellas, L.P.; Olivares, F.L.; Canellas, N.O.; Mazzei, P.; Piccolo, A. Humic acids increase the maize seedlings exudation yield. Chem. Biol. Technol. Agric. 2019, 6, 3. [CrossRef] 